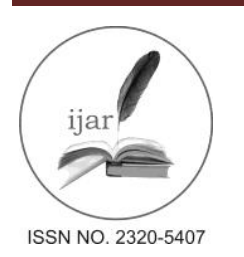

Journal homepage: http://www.journalijar.com

INTERNATIONAL JOURNAL

OF ADVANCED RESEARCH

RESEARCH ARTICLE

\title{
EFFECT OF IRON AND VITAMIN C FORTIFIED CANDIES ON THE IRON STATUS OF EARLY TEENAGER.
}

\author{
Nehad R. EL-Tahan ${ }^{1}$, Nehal A. A. Alfky². \\ 1. Nutrition and Food Science Dept., Faculty of Home Economics, Minufiya University. \\ 2. Clinical Nutrition Department, Faculty of Applied Medical Sciences, Umm al Qura, University, KSA.
}

\section{Manuscript Info}

Manuscript History:

Received: 18 January 2016

Final Accepted: 29 February 2016

Published Online: March 2016

Key words:

Anemia- candy-ferric hydroxide hemoglobin

*Corresponding Author

Nehad R. EL-Tahan.

\begin{abstract}
Iron deficiency anemia is the most nutrition problem in teenager period. One possible strategy to prevent iron deficiency anemia in this group is the fortification of favorite food as candy. So, this study was designed to know the effect of iron and vitamin $\mathrm{C}$ fortified candies on the iron status of teenager aged 10-16 y. The female teenager were randomly assigned to 3 treatment groups: A fortified group with iron $(n=20)$, fortified group with vitamin $\mathrm{C}(n=20)$ and a control group $(n=20)$. Candy was given to the teenager every day for $12 \mathrm{wk}, 5 \mathrm{~g}$ (1 piece).

The candy given to the fortified group contained $1 \mathrm{mg}$ elemental $\mathrm{Fe}$ ( Ferric hydroxide) /g candy and $1 \mathrm{mg}$ vitamin $\mathrm{C}$ (Ascorbic acid) / g candy. The results showed that the hemoglobin concentration of the fortified groups increased to $10.6 \mathrm{~g} / \mathrm{L}$ and $11.2 \mathrm{~g} / \mathrm{L}$ in group 3 and from 10.6 to 12.8 in group 2 whereas that of the control group was $10.6 \mathrm{~g} / \mathrm{L}$. Anemia decreased from $50.9 \%$ at the control group to $8.8 \%$ in group 2 and 13.3 in group 3 after 12 wk $(P \leq 0.05)$ and, the serum ferritin concentration was lower in the control group than the fortified groups with iron and vitamin $\mathrm{C} \quad(P \leq 0.05)$. From these results, it could be recommended that Iron and vitamin $\mathrm{C}$ fortified candies were effective for improving the iron status of teenager aged 10-16y and might be a good way to decrease iron deficiency in teenager of low-tomiddle income groups.
\end{abstract}

Copy Right, IJAR, 2016. All rights reserved.

\section{Introduction:-}

Iron deficiency anemia is still the most prevalent nutrition problem worldwide (Yip R, 1999). Iron anemia caused by insufficient dietary intake and absorption of iron, and/or iron loss from bleeding which can originate from a range of sources such as the intestinal, uterine or urinary tract. Iron deficiency causes approximately half of all anemia cases worldwide, and affects women more often than men. World estimates of iron deficiency occurrence are somewhat vague, but the true number probably exceeds one billion people ( Calis et al., 2008). Young children are a particularly vulnerable group and the prevalence of anemia in this population category in east is $50-70 \%$. The most significant cause of iron-deficiency anemia in third world children is parasitic worms: hookworms, whipworms, and roundworms. Worms cause intestinal bleeding, which is not always noticeable in faces, and is especially damaging to growing children (Albonico et al., 1994 and Angeles et al., 1995). One of the causes of nutritional anemia is that the amount of iron absorbed is insufficient to meet the body's requirements. This insufficiency may be due to both inadequate iron intake from food and to low bioavailability (DeMaeyer, 1989). Children consume less food than do adults and their diet often consists of foods with a low iron content and in which the bioavailability of iron is poor (Stekel, 2000).

Anemia during childhood may lead to impaired motor development, decreased growth and appetite, reduced learning capacity, and reduced cognitive performance, and is also associated with poorer performance of the 
immune system (Salon, 2008). Therefore, an adequate supply of iron to all tissues during this critical period of development is essential (Stekel,2000). In the relatively short term, an improvement in the situation can be expected only through interventions such as food fortification or medicinal iron tablets or syrup. Although the Indonesian Ministry of Health supports iron fortification of food as one of the main strategies to prevent iron deficiency anemia, with young children being among the priority target groups (Mejia and Arroyave, 1999) studies on the fortification of food with iron are scarce in Indonesia.

Ascorbic acid is a sugar acid with antioxidant properties. Its appearance is white to light-yellow crystals or powder, and it is water-soluble. One form of ascorbic acid is commonly known as vitamin C. Ascorbic acid is used as an antioxidant and $\mathrm{pH}$ adjuster in a large variety of cosmetic formulations, over 3/4 of which were hair dyes and colors at concentrations between $0.3 \%$ and $0.6 \%$ (Mukhtar et al., 1995). Ascorbic acid performs numerous physiological functions in human body. These functions include the synthesis of collagen, carnitine and neurotransmitters, the synthesis and catabolism of tyrosine and the metabolism of microsome (Prockop and Kivirikko,1995). Vitamin C for the growth and repair of tissues in all parts of your body. It helps the body make collagen, an important protein in skin, cartilage, tendons, ligaments, and blood vessels. Vitamin C enhances iron absorption and essential for healing wounds, and for repairing and maintaining bones and teeth (Diplock, 1999). Vitamin C is absorbed by the intestines using a sodium-ion dependent channel. It is transported through the intestine via both glucose-sensitive and glucoseinsensitive mechanisms. The presence of large quantities of sugar either in the intestines or in the blood can slow absorption (Wilson, 2005). According to McGregor and Biesalski (2006), the plasma ascorbate concentration in oxidative stress patient (less than $45 \mu \mathrm{mol} / \mathrm{L})$ measured is lower than healthy individual $(61.4-80 \mu \mathrm{mol} / \mathrm{L})$. Increasing plasma ascorbate level may have therapeutic effects in oxidative stress individual. Individuals with oxidative stress and healthy individuals have different pharmacokinetics of ascorbate (Bjelakovic, 2007). Vitamin C is necessary for the treatment and prevention of scurvy. Scurvy is commonly comorbid with other diseases of malnutrition; sufficient vitamin $\mathrm{C}$ to prevent scurvy occurs in most diets in industrialized nations (Shenkin, 2006).

The identification of a suitable vehicle is an important consideration in any attempt to fortify foods. Cereal products have traditionally been used as vehicles for fortificant iron in many countries . Other vehicles used include sugar, fish sauce, common salt, and cookies (Nestel, 1993). Sweets are attractive foods to children and are therefore suitable as a carrier of fortificants for this reason and others. First, the fortification of a staple food is difficult to control, the variation in intake between individuals is large, and the consumption is not limited to specific at-risk groups. Second, in Indonesia, sweets are also eaten by the poorer segments of the population, especially by children.

This study was designed to investigate the effect of both iron and vitamin $\mathrm{C}$ fortified on improvement the iron status of children( Female) aged 10-16y and whether they would be acceptable to them. Both the fortified and placebo candies used in this study were candies specifically prepared by candies specializer. In fact, the same unfortified candies had already been produced and marketed by the same company.

\section{Subjects and methods:- \\ Subjects:-}

The study was carried out between early March and early June 2011 in 2 primary and prep school in the Shebin ELKom, Minufiya Governorate, Egypt. Subjects were female aged 10-16 y from low-to-middle income groups who were apparently healthy and had a hemoglobin concentration less than $80 \mathrm{~g} / \mathrm{L}$. With a sample size of 60 children/group, a difference in the change in hemoglobin concentration of $\pm 2 \mathrm{mg} / \mathrm{L}$ between groups

\section{Methods:-}

The macronutrient content of $100 \mathrm{~g}$ candy, as declared by the manufacturer, was $1 \mathrm{~g}$ starch, $45 \mathrm{~g}$ glucose, $44 \mathrm{~g}$ fructose, $3 \mathrm{~g}$ saccharose, and $7 \mathrm{~g}$ bovine protein. These ingredients mixed at $80^{\circ} \mathrm{C}$ for one hour (Walter et al., 1993).

The study was double-blinded and placebo-controlled with random allocation of children to treatment groups. A hemoglobin concentration $<110 \mathrm{~g} / \mathrm{L}$ was used as a cutoff for defining anemia, whereas a serum ferritin concentration $<20 \mathrm{mg} / \mathrm{L}$ was used as the cutoff for defining iron deficiency. The 60 subjects enrolled initially were randomly assigned to three groups: a placebo group $(n=20)$ and a fortified group with iron $(n=20)$ and fortified with vitamin $\mathrm{C}(\mathrm{n}=20)$. For $12 \mathrm{wk}$, the placebo group received nonfortified candies and the fortified groups received iron and vitamin $\mathrm{C}$ fortified candies, which provided a total of $30 \mathrm{mg}$ elemental Fe/wk (48\% of the recommended dietary allowance for children aged $9-11 \mathrm{y})$ and $30 \mathrm{mg}$ vitamin $\mathrm{C}(60 \%$ of the recommended dietary allowance for children 
aged 9-11 y). Iron and vitamin $\mathrm{C}$ fortified and placebo candies were individually packed in a transparent wrapper that was labeled as either A or B or C. The coding was known only to the manufacturer and was revealed only after the study and the analyses were completed.

The candies were distributed daily (1 piece). The distribution and consumption of the candies were supervised directly by teachers. The subjects who were absent on the days the candy was distributed received candies the next day.

\section{Anthropometric assessment:-}

Both at baseline and after $12 \mathrm{wk}$ of intervention, the weight and height of the subjects were measured and their hemoglobin and serum ferritin concentrations were assessed a. Weight was determined with an electronic bathroom model scale (model 890; Seca, Hamburg, Germany) and was recorded to the nearest $0.1 \mathrm{~kg}$. Height was measured by using a microtoise with an accuracy of $0.1 \mathrm{~cm}$ while the subjects were shoeless.

\section{Laboratory assessment:}

Blood samples $(2 \mathrm{~mL})$ were collected from apparently healthy subjects twice - at baseline and after 12 wk of intervention - by venipuncture by a trained technician. Immediately after collection, part of the sample was removed for determined of hemoglobin concentrations by the cyanomethemoglobin method (Merck-test 3317; Merck, Darmstadt, Germany) (INACG). Subjects with initial hemoglobin concentrations $<80 \mathrm{~g} / \mathrm{L}$ were excluded from the study. The remaining blood was placed in ice, protected from light, and centrifuged $(750 \times \mathrm{g}$, $10 \mathrm{~min}$, room temperature) at the laboratory of EL- Borg within a few hours. The serum obtained was frozen at $-20^{\circ} \mathrm{C}$ for later measurement of ferritin concentrations. Serum ferritin concentrations were measured within $1 \mathrm{mo}$ after blood collection by using the enzyme immunoassay method (IMx System; Abbott, Abbott Park, IL) McInory (1954). Both assessments were performed at the laboratory of EL- Borg and 15\% of the blood samples were analyzed twice. CVs based on these duplicate measurements were $3.9 \%$ for hemoglobin and $5.5 \%$ for serum ferritin.

In the first week of the intervention, all students were invited to come to room meeting for an interview about their socioeconomic background, the health of them, and the acceptability of the fortified candies.

\section{Supplement}

The supplement used in this study, lollypop, was fruit-flavored, and sweet and both the fortified and nonfortified candies were prepared by candy specializer. The vitamins of the candies were determined at the beginning of the study according to methods reported by (Butera et al., 2002).

\section{Statistical analysis:-}

Standard error and ANOVA test followed by the student $t$-test for significant difference. Statistical significant difference was defined as $\mathrm{P}<0.05$ (Snedecor and Cochran, 1976).

\section{Results:-}

One fortified candy $(5 \mathrm{~g}$ ) contained $5 \mathrm{mg}$ of Fe or vitamin $\mathrm{C}$ insignificant amounts of other minerals and vitamins (Table 1). The placebo candy was not fortified and therefore did not contain a significant amount of any vitamins or minerals.. To ensure a weekly dose of $30 \mathrm{mg} \mathrm{Fe}, 6$ candies were provided per week, divided daily . Both the fortified and placebo candies had an orange flavor, which had been chosen by the manufacturer because of large overall acceptance and preference.

Table 1. Micronutrient content of $30 \mathrm{~g}$ (weekly dose) iron and vitamin $\mathrm{C}$ fortified candies.

\begin{tabular}{|l|l|l|l|}
\hline Nutrient & Control candy & $\begin{array}{l}\text { Fortified candy } \\
\text { with Fe }\end{array}$ & $\begin{array}{l}\text { Fortified candy } \\
\text { with vitamin C }\end{array}$ \\
\hline Iron $(\mathrm{mg})$ & - & 30 & 30 \\
\hline Vitamin $\mathrm{A}^{3}$ & 337 & 337 & 337 \\
\hline Thiamine & 0.2 & 0.2 & 0.2 \\
\hline Riboflavin & 0.4 & 0.4 & 0.4 \\
\hline Vitamin B-6 & 0.36 & 0.36 & 0.36 \\
\hline
\end{tabular}

The age, weight, and height, of the subjects in both treatment groups after $12 \mathrm{wk}$ of intervention are shown in table (2). 
Table 2: Age and anthropometric measures of subjects after 12 wk of intervention by treatment group. $\underline{\mathrm{Adv}}$

\begin{tabular}{|l|c|c|c|}
\hline $\begin{array}{l}\text { Characteristic } \\
\overline{\mathrm{x}} \pm \text { SD. }\end{array}$ & $\begin{array}{l}\text { Control group }(\mathrm{n}= \\
\text { 20) }\end{array}$ & $\begin{array}{l}\text { Fortified with fe } \\
\text { group }(\mathrm{n}=20)\end{array}$ & $\begin{array}{l}\text { Fortified with vitamin } \\
\text { group }(\mathrm{n}=20)\end{array}$ \\
\hline Age $(\mathrm{y})$ & $10.7^{\mathrm{a}} \pm 2.7$ & $10.9^{\mathrm{a}} \pm 3.7$ & $10.8^{\mathrm{a}} \pm 4.3$ \\
\hline Weight $(\mathrm{kg})$ & $45.5^{\mathrm{a}} \pm 2.6$ & $46.8^{\mathrm{a}} \pm 2.7$ & $46.9^{\mathrm{a}} \pm 2.3$ \\
\hline Height $(\mathrm{cm})$ & $158.2^{\mathrm{a}} \pm 5.2$ & $159.9^{\mathrm{a}} \pm 5.4$ & $158.0^{\mathrm{a}} \pm 5.1$ \\
\hline
\end{tabular}

Non significant difference between treatment groups compared with control group, $\mathrm{P}<0.05$ (Student's t test).

\section{Effect of iron and vitamin $\mathbf{C}$ fortified candies on iron status:-}

The effects of the treatment on the children's iron status are shown in Tables (3). Weekly consumption of iron and vitamin $\mathrm{C}$ fortified candies significantly improved iron status. After the 12 -wk intervention, the hemoglobin concentration, corrected for baseline, was higher in the fortified group than in the control group and this increase was nonsignificant. The same was found among the anemic subjects. The serum ferritin concentration after 12 wk of intervention was significantly higher in the fortified groups than the control group $(\mathrm{P}<0.05)$. The prevalence of anemia and iron deficiency, at the beginning of the study and after $12 \mathrm{wk}$ of intervention, per treatment group, are shown in table (4). Although the prevalences of anemia and iron deficiency decreased significantly in both treatment groups after $12 \mathrm{wk}$ of intervention, the prevalence of anemia was significantly lower in the fortified group.

Table 3 : Hemoglobin and serum ferritin concentrations before and after 12 wk of consumption of iron and vitamin $\mathrm{C}$ fortified or control candies.

\begin{tabular}{|l|l|l|l|}
\hline $\begin{array}{l}\text { Characteristic } \\
{ }^{l} \overline{\mathrm{x}} \pm \text { SD. }\end{array}$ & $\begin{array}{l}\text { Control group }(n= \\
20)\end{array}$ & $\begin{array}{l}\text { Fortified with Fe } \\
\text { group }(n=20)\end{array}$ & $\begin{array}{l}\text { Fortified with vitamin } \\
\text { group }(n=20)\end{array}$ \\
\hline Hemoglobin (g/L) & $10.6^{\mathrm{a}} \pm 3.7$ & $12.8^{\mathrm{a}} \pm 2.8$ & $12^{\mathrm{a}} \pm 4.0$ \\
\hline $\begin{array}{l}\text { Serum ferritin } \\
(\mu \mathrm{g} / \mathrm{L})\end{array}$ & $19^{\mathrm{b}} \pm 1.7$ & $32^{\mathrm{a}} \pm 5.9$ & $31^{\mathrm{a}} \pm 3.7$ \\
\hline
\end{tabular}

Values significantly different compared to normal: $P \leq 0.05$. Same letter means non-significant.

Table 4: Prevalence of anemia and iron deficiency in the 3 groups after 12 wk of intervention

\begin{tabular}{|l|l|l|l|}
\hline $\begin{array}{l}\text { Characteristic } \\
{ }^{l} \overline{\mathrm{x}} \pm \text { SD. }\end{array}$ & $\begin{array}{l}\text { Control group }(n= \\
20)\end{array}$ & $\begin{array}{l}\text { Fortified with Fe group } \\
(n=20)\end{array}$ & $\begin{array}{l}\text { Fortified with vitamin } \\
\text { group }(n=20)\end{array}$ \\
\hline Anemia (\%) & $50.9^{\mathrm{a}} \pm 1.6$ & $8.8^{\mathrm{b}} \pm 3.7$ & $13.3^{\mathrm{b}} \pm 2.3$ \\
\hline Iron deficiency (\%) & $52.6^{\mathrm{a}} \pm 1.7$ & $17.5^{\mathrm{b}} \pm 0.7$ & $19.7^{\mathrm{b}} \pm 1.2$ \\
\hline
\end{tabular}

Significantly different from prevalence at $P<0.05$. Anemia defined as a hemoglobin concentration $<11.0 \mathrm{~g} / \mathrm{L}$. Iron deficiency $(\%)$ defined as a serum ferritin concentration $<20 \mu \mathrm{g} / \mathrm{L}$.

\section{Discussion:-}

The results of the present study indicate that the iron and vitamin $\mathrm{C}$ fortified candies, which provided $48 \%$ of the recommended dietary allowance of iron and vitamin $\mathrm{C}$ per week, were acceptable to children aged 10-16 $\mathrm{y}$ and improved their iron status.

Iron deficiency is common in developing countries, where the diet is largely cereal-based and contains little animal protein (Clydesdale and Wiener , 2005), and it will take a long time for dietary changes to result in improvements in iron status. One way to ensure the adequate iron nutrition of a population is to fortify commonly consumed foods with iron or vitamin $\mathrm{C}$ to enhance the utilization of iron and provide the foods in relatively predictable amounts (Mega and Chen, 2007). Food fortification and supplementation are generally considered the best approaches for combating iron deficiency in a population. However, fortified foods do not always reach the intended target groups. Therefore, this study amied to ensure the effect of the consumption of fortified candies that are mainly consumed by children, including those of low-to-middle income groups.

The increase in hemoglobin concentrations in the anemic subjects, $12.9 \mathrm{~g} / \mathrm{L}$, is similar to the $12-\mathrm{g} / \mathrm{L}$ increase observed in a study of children aged $<16$ y supplemented weekly with $30 \mathrm{mg}$ elemental Fe or vitamin $\mathrm{C} /$ wk (Hallerg 
et al., 2009). The increase in serum ferritin concentrations in anemic subjects of $15 \mu \mathrm{g} / \mathrm{L}$ [calculated from results reported in table4: median value at baseline $(17 \mu \mathrm{g} / \mathrm{L}) \times$ the proportional change $(85 \%)]$ is comparable with the results of a study in which anemic children were supplemented with both vitamin $\mathrm{C}$ and iron, and in which serum ferritin increased by $16.4 \mu \mathrm{g} / \mathrm{L}$. These values are slightly higher than those observed in studies of the effects of ironfortified soup and of iron-fortified curry powder (Hunt et al., 1994).

The improvement in iron status after consumption of iron-fortified candies was most likely due to the iron content of the candies. The candies also contained micronutrients, such as vitamins $\mathrm{C}$ (which is known to improve iron absorption and utilization), respectively (Hallerg et al., 2009), and other hematopoietic nutrients such as vitamin B12 , and vitamin B-6, (which are known to increase hemoglobin concentrations), the content of these micronutrients was so small that it is unlikely that they contributed to the improvement in iron status.

In summary, It could be concluded that consumption of 10 pieces of iron and vitamin $\mathrm{C}$ fortified candy that provided $30 \mathrm{mg}$ elemental $\mathrm{Fe}$ or vitamin $\mathrm{C} / \mathrm{wk}$ was acceptable to the target group and is a feasible and effective way to improve the iron status of children aged 10-16 y. However, because of the current economic situation in egypt, introduction of this strategy to improve the iron status of children is less likely than it was at the time that the study was conducted.

\section{References:-}

1. Albonico, M.; Smith, P.G.; Hall, A;. Chwaya, H.M.; Alawi, K.S. and Savioli, L. A. (1994): Randomised controlled trial comparing mebendazole and albendazole against ascaris, trichuris and hookworm infection. Trans. R. Soc. Trop. Med. Hyg., 88:585-591.

2. Angeles, I.T.; Schultink, W.J.; Matulessi, P.; Gross, R. and Sastroamidjojo, S.(1995): Decreased rate of stunting among anemic Indonesian preschool children through iron supplementation. Am. J. Clin. Nutr., 58:339-42.

3. Bjelakovic, G. (2007): Mortality in randomized trials of antioxidant supplements for primary and secondary prevention: Systematic review and meta-analysis. J. A. M. A., 297 (8): 842-57.

4. Butera, D.; Tesoriere, L.; Di and Gaudio, F. (2002): Antioxidant activities of Sicilian prickly pear (Opuntia ficus indica) fruit extracts and reducing properties of its betalains: betanin and indicaxanthin. J .Agric. Food Chem.,50:6895-901.

5. Calis, J.C.; Phiri, K.S. and Faragher, E.B. (2008): "Severe anemia in Malawian children". N. Engl. J. Med., 358 (9): 888-99.

6. Clydesdale, F.M. and Wiener, K.L.(2005): Iron fortification of foods. Orlando, FL: Academic Press,1-170.

7. DeMaeyer, E.M.; Dallman, P.; Gurney, J.M.; Hallberg, L.; Sood, S.K.; Srikantia, S.G.(1989): Preventing and controlling iron deficiency anemia through primary health care. Geneva: World Health Organization.

8. Diplock, A. T. (1999): Safety of antioxidant vitamins and beta-carotene. Am. J. Clin. Nutr., 62 (6): 1510S1516S.

9. Hallerg, L.; Sandstrom, B. and Aggett, P.J.( 2009): Iron, zinc, and vitamin C elements. In: Garrow JS, James WPT, ed. Human nutrition and dietetics. New York: Churchill Livingstone.

10. Hunt, J.R.; Gallagher, S.K. and Johnson, L.K.(1994): Effect of ascorbic acid on apparent iron absorption by women with low iron stores. Am. J. Clin. Nutr. 59:1381-5.

11. McGregor, G. P. and Biesalski, H. K. (2006): Rationale and impact of vitamin C in clinical nutrition. Curr. Opin. Clin. Nutr. Metab. Care, 9:697-703

12. McInory, R. A. (1954): A micro serum frettin for determine. The packed cell volume and hemoglobin concentration in capillary blood. J. Clin. Path.,, 7:32.

13. Mega, L.A. and Chen, F.( 2007): Hematological effect of supplementing anemic children with vitamin A alone and in combination with iron. Am. J. Clin. Nutr .,48:595-600.

14. Mejia, L.A. and Arroyave, G. ( 1999): The effect of vitamin C fortification of sugar on iron metabolism in preschool children in Guatemala. Am. J. Clin. Nutr . 36:87-93.

15. Mukhtar, H. M.; Ansari, S. H.; Bhat, Z. A.; Naved, T. and Singh, P. (1995): Antidiabetic activity of an ethanol extract obtained from the stem bark of Psidium guajava (Myrtaceae). Pharmazie. 61 (8): 725-727.

16. Nestel P. (1993): Food fortification in developing countries. Washington, DC: USAID.

17. Prockop, D. J. and Kivirikko, K. I. (1995): Collagens: molecular biology, diseases, and potentials for therapy. Annu. Rev. Biochem., 64: 403-34.

18. Salon F. (2008) Iron and food supplementation delivery project, summary of findings and recommendation. Manila, Philippines: Nutrition Center of the Philippines. 
19. Shenkin, A. (2006): The key role of micronutrients. Clin. Nutr., 25 (1): 1-13.

20. Snedecor, G. W. and Cochran, W. G. (1976): Statistical Methods. $6^{\text {th }}$ Ed.,. Ames, Iowa state's Univ. Press, 298.

21. Stekel, (2000): Prevention of iron deficiency. In: Iron nutrition in infancy and childhood. Jakarta, Indonesia: Nestle Nutrition, PT Food Specialties , 49-53.

22. Walter T, Hertrampf E, Pizarro F, et al. Effect of bovine-hemoglobin-fortified cookies on iron status of schoolchildren: a nationwide program in Chile. Am J Clin Nutr 1993;57:190-4.

23. Wilson, J. X. (2005): Regulation of vitamin C transport. Annu. Rev. Nutr., 25: 105-25.

24. Yip, R. (1999): Iron deficiency: contemporary scientific issues and international programmatic approaches. J .Nutr., 124:1479S-90S. 